\title{
$\mathrm{LNG}$ 선박용 알루미늄 합금 소재의 정적 및 피로 강도 평가
}

\author{
윤용근 · 김재훈 ${ }^{\star}$ 김우중 · 백경호* · 박창현 \\ 충남대학교 기계설계공학과 - * 충남대학교 나노소재공학과 \\ (2012. 7. 27. 접수 / 2013. 3. 10. 채택)
}

\section{Assessment for Static and Fatigue Strength of the Aluminum Alloy for LNG Ship}

\author{
Yong Keun Yoon · Jae Hoon $\mathrm{Kim}^{\dagger} \cdot$ Woo Joong Kim $\cdot$ Kye Ho Baik ${ }^{*} \cdot$ Chang Hyun Park \\ Department of Mechanical Design Engineering, Chungnam National University. \\ *Department of Nano Materials Engineering, Chungnam National University.
}

(Received July 27, 2012 / Accepted March 10, 2013)

\begin{abstract}
Liquefied Natural Gas is liquefied at the condition of atmosphere pressure and cryogenic temperature. LNG is exposed very long time under the cryogenic temperature and high pressure, and it is very important to retain the structural safety in this envelopment. Until now, the material which are composing the storage tank of LNG ship has experimented at room temperature, so it is not enough to apply for the design at the cryogenic temperature. The purposes of this study are investigated mechanical properties for aluminum alloy. To evaluate tensile and fatigue test for aluminum alloy, it was considering static and fatigue conditions at room and cryogenic temperature. S-N curves were designed at both temperature respectively. Also, P-S-N curve was performed statistical method by JSME-S002.
\end{abstract}

Key Words : aluminum alloy, tensile test, fatigue test, cryogenic temperature, LNG ship

\section{1. 서 론}

지속적인 산업화에 따른 지구의 환경오염 문제가 심각 하게 제기되면서 $\mathrm{LNG}$ 는 깨끗하고 사용이 편리하다는 점 에서 가장 유망한 대체 에너지원으로 등장하여 가정용, 상 업용, 산업용으로 매우 다양하게 사용되고 있다. LNG가 가 진 초저온이라는 특성 때문에 이에 대응할 수 있는 강도와 인성을 가진 초저온용 재료를 내벽재료로 사용하여야 한다. 알루미늄 합금이 선박 건조로 대체될 경우 내구성이 좋고, 선체가 경량화 되기 때문에 선속 증가, 적재량의 증가, 생력 화와 관련지을 수 있으며 무엇보다 중요한 것은 재활용이 가능하다는 점이다 ${ }^{1)}$. 또한, 5000 계열 알루미늄 합금은 $\mathrm{Mg}$ 이 주 첨가 성분으로 강도, 해수환경 하에서 내식성이 우수하여 해양 구조물에 많이 사용된다. 따라서 중소형 선박 건조의 신소 재로 경도 및 경량성이 우수하며 특히 내식성이 뛰어나 해수 환경 하에서 선박용 부품 및 해양 구조물에 널리 이용되 는 알루미늄 합금이 최적의 재료로서 관심이 고조되고 있다.

LNG 탱크 설계와 제작 시 가장 중요하게 고려되는 것은 조업 중 탱크 외부로의 $\mathrm{LNG}$ 누출방지이다. 이를 위해서는 LNG 탱크 구조에 대한 상세한 응력해석을 통해 결정된 정적하중을 기초로 한 안전 설계가 기본이나, LNG 탱크는 운항 중 발생되는 선체진동, 탱크 내의 액체유동 및 파랑 하중 등의 피로하중을 받기 때문에 피로설계 역시 반드시
수반되어야 한다 ${ }^{2)}$.

본 연구에서 사용된 알루미늄 합금은 LNG 선박용 저장 탱크 내부에 사용되는 재료로 Al-MG계 합금이다. 이 재료 는 소재의 국산화를 위하여 개발 중인 LNG 선박용 알루미 늄 합금이다.

따라서 개발된 LNG 선박용 알루미늄 합금 (Al 5083 합금) 에 대하여 상온 및 극저온 환경 하에서 알루미늄 합금 소 재의 정적 및 피로강도 평가를 수행하였다. 또한, 재료의 피로수명 및 특성을 평가하기 위해 S-N 선도를 도출하였 다. 여기에 통계적인 방법을 추가하여 P-S-N 선도로 확장시 켰다. 마지막으로 합금의 개재물이 재료의 기계특성에 끼 치는 영향을 알아보기 위해 개재물 추출법을 통한 재료의 정 성, 정량 분석을 실시하였다.

\section{2. 재료 및 시험 방법}

\section{1. 재료 및 시험편}

본 실험에서 사용한 소재는 압연한 5083 알루미늄 합금 (Al 5083 합금)으로 화학적 성분은 Table 1과 같다. $\mathrm{Mg}$ 함 량은 $4.5 \%$ 이고 $\mathrm{Mn}$ 함량은 $0.70 \%$ 이다. 소재는 두께 $25 \mathrm{~mm}$ 판재로서 길이 방향으로 시험편을 채취하였다. 시험편은 ASTM $\mathrm{E} 8^{3)}$ 와 $\mathrm{E} 466^{4)}$ 에 따라 인장 및 피로 시편을 Fig. 1과 같이 제작 및 가공하였다. 
Table 1. Chemical compositions of modified $9 \mathrm{Cr}-1 \mathrm{Mo}$ steel(wt\%)

\begin{tabular}{c|c|c|c|c|c|c|c}
\hline $\mathrm{Si}$ & $\mathrm{Fe}$ & $\mathrm{Cu}$ & $\mathrm{Mn}$ & $\mathrm{Mg}$ & $\mathrm{Cr}$ & $\mathrm{Zn}$ & $\mathrm{Ti}$ \\
\hline \hline 0.15 & 0.15 & 0.02 & 0.70 & 4.50 & 0.15 & 0.02 & 0.15 \\
\hline
\end{tabular}

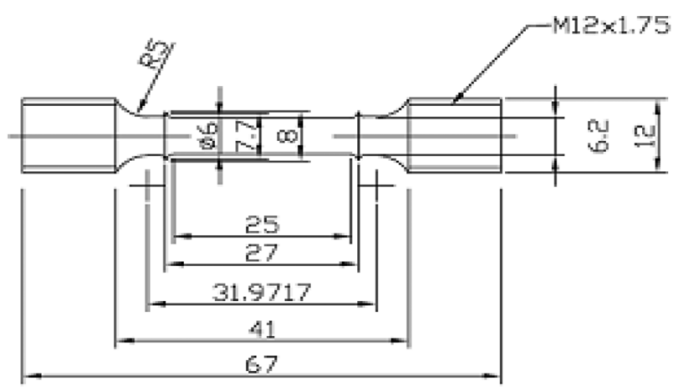

(a) Tensile specimen

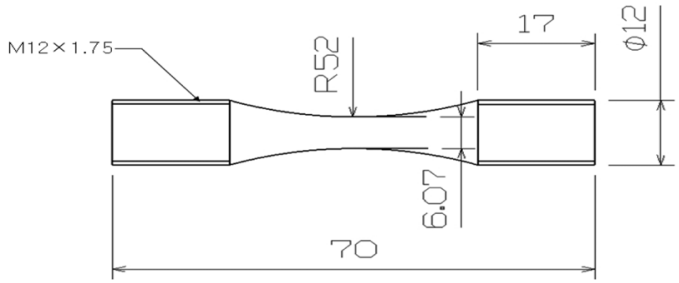

(b) Fatigue specimen

Fig. 1. Configuration and dimension of specimen.

\section{2. 인장 시험}

실험은 만능 재료 시험 장비(MTS810)를 사용하여 실시 하였다. 실험에서는 최대하중 $10 \mathrm{kN}$ 용 로드셀에서 익스텐소 미터(extensometer) 및 스트레인게이지(strain gauge)를 사용 하여 변형을 측정하였고 $2 \mathrm{~mm} / \mathrm{min}$ 의 속도로 변위 제어 방 식을 사용하여 하중-변위 데이터를 얻었다. Fig. 2은 스트레 인게이지를 시편에 부착한 모습을 보여주고 있다. Fig. 3 과 같은 저온용 챔버를 사용하여 저온 환경을 유지하였으며 실 험온도는 상온, $-40^{\circ} \mathrm{C},-80^{\circ} \mathrm{C},-120^{\circ} \mathrm{C}$ 및 $-170^{\circ} \mathrm{C}$ 이다.

\section{3. 고주기 피로 시험}

고주기피로 성질 평가의 시험기는 인장 실험과 동일한 10 ton 용량의 MTS810으로 부하 속도는 $25 \mathrm{~Hz}$ 의 일정 진 폭하중, 응력비 $(\mathrm{R})=0.1$ 의 인장-인장으로 실험하였다. 실 험온도는 상온과 $-170^{\circ} \mathrm{C}$ 에서 실험을 실시하였다. 또한, JSME

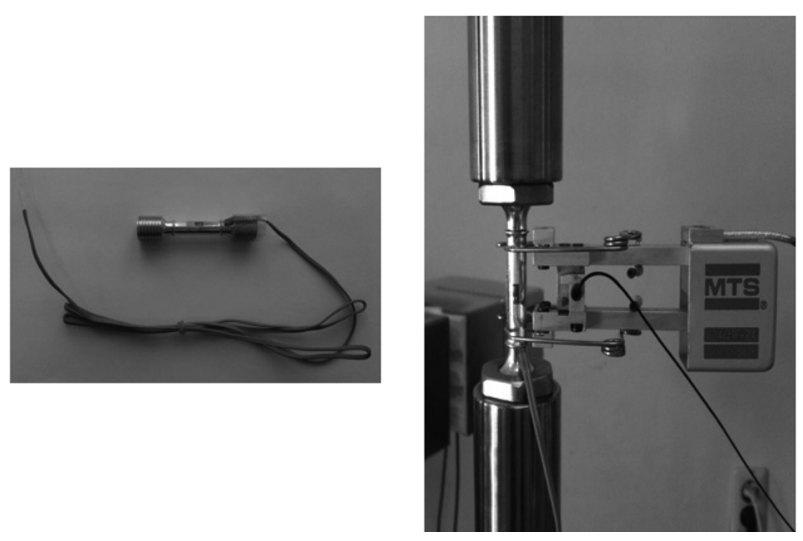

Fig. 2. Configuration of experimental apparatus.
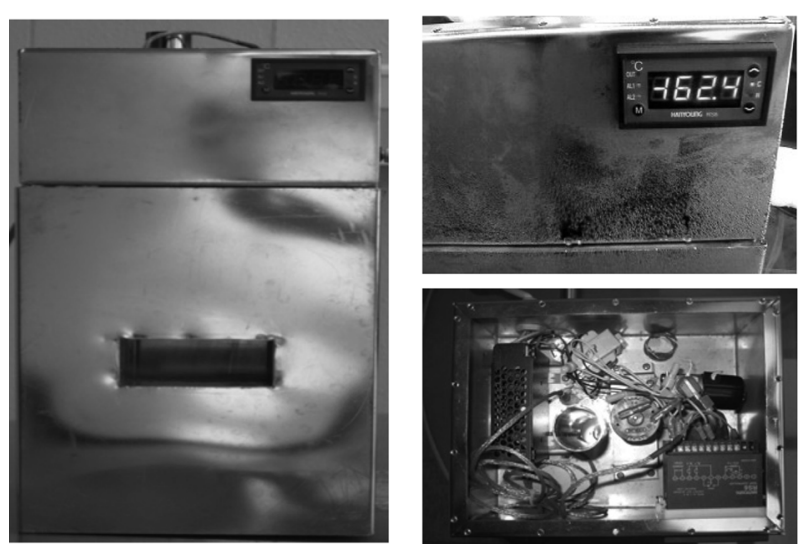

Fig. 3. Configuration of chamber equipment.

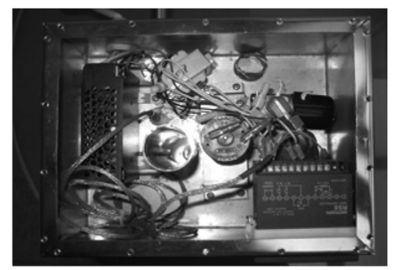

S-002에서 제시한 통계적 기법에 따라 파괴확률 $50 \%$ 의 S-N 선도와 파괴확률 $10 \%$ 및 $90 \%$ 의 S-N 선도를 작성하였다.

\section{4 개재물 추출}

시편을 $5 \mathrm{~g}$ 이 넘지 않도록 절단 해준 후 끓고 있는 페 놀에 시편을 넣는다. 반응이 끝나면 페놀에 $100 \mathrm{~mL}$ 의 벤 질 알콜을 즉시 부어준다. 그 후 온도가 떨어지면 알루미 늄 페놀레이트가 형성될 수 있으므로 바로 원심분리를 한 다. 이때, 원심 분리 조건은 $10000 \mathrm{rpm}$, 온도 $25^{\circ} \mathrm{C}$ 에서 15 분 간 분리하였다. 얻어진 잔여물은 벤질 알콜과 메탄올에서 두 번 세척 후 다시 원심분리를 10 분간 실시한다. 그 후 최종적 으로 얻어진 잔사를 가지고 $\mathrm{EDX}, \mathrm{XRD}$ 분석을 하였다.

\section{3. 결과 및 고찰}

\section{1. 인장시험 결과}

인장실험은 상온과 $-40^{\circ} \mathrm{C},-80^{\circ} \mathrm{C},-120^{\circ} \mathrm{C}$ 및 $-170^{\circ} \mathrm{C}$ 의 온 도 조건에서 각 3 회씩 시험을 실시하였다. 시험 결과로부터 항복강도, 인장강도, 탄성계수, 연신율 및 단면 감소율을 구 하였다.

Fig. 4는 항복강도와 인장강도를 나타낸 것이다. 항복강 도와 인장강도는 상온과 $-80^{\circ} \mathrm{C}$ 범위안의 온도범위에서 온도가 낮아짐에 따라 다소 감소하는 경향을 보인 후 $-120^{\circ} \mathrm{C}$ 이 후 증가하는 것을 알 수 있다. 결정립계의 구조가 $\mathrm{BCC}$ 구조를

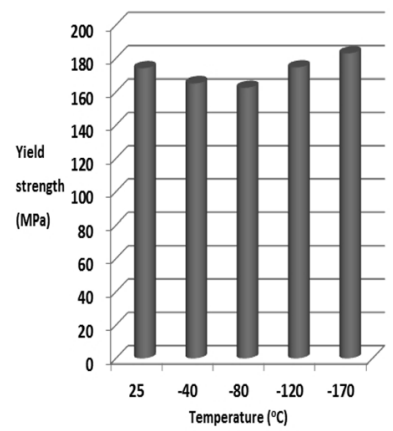

(a) Yield strength

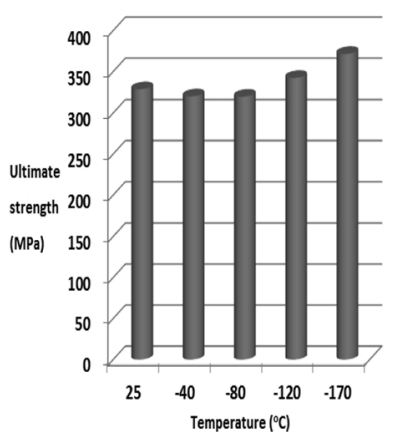

(b) Ultimate strength
Fig. 4. Comparison of yield and ultimate strength for specimens. 


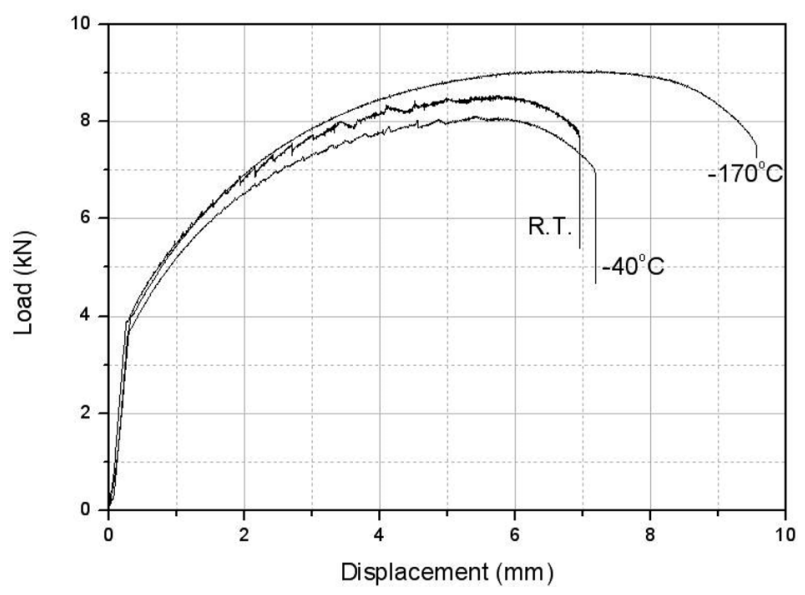

Fig. 5. Comparison of load-displacement at different temperatures,

지닌 5000계열 알루미늄 합금은 온도가 낮아짐에 따라 강도 가 증가하는 경향성이 있다. 그러나 본 실험에서는 $-80^{\circ} \mathrm{C}$ 까 지 강도가 감소하는 것을 확인 할 수 있다. 강도가 상온과 저 온에서 높고 중간 온도에서 낮은 이유는 Fig. 5의 하중-변위 선도에서 나타나는 톱니형상(serration)과 관계가 있다. $-170^{\circ} \mathrm{C}$ 선도에서는 나타나지 않으며, 상온의 선도 보다는 작은 폭 의 톱니형상이 $-40^{\circ} \mathrm{C}$ 에서 발견되었다. 온도의 영향을 많이 받는 톱니형상은 저온에서는 확산속도가 느려 변형이 일 어나지 않는 것으로 판단된다. $-40^{\circ} \mathrm{C}$ 에서는 조밀한 톱니형 상이 진행됨으로써 국부적으로 가공경화를 받아 강도가 낮 게 나타났다고 추정되며, 상온은 큰 폭의 톱니형상이 생기

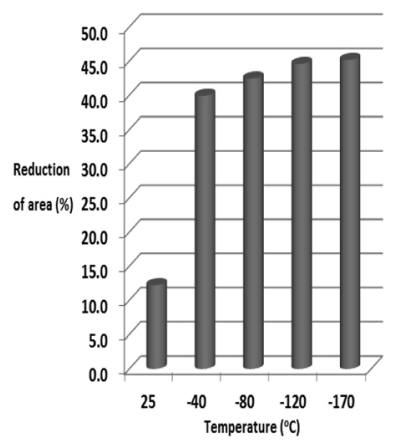

(a) Reduction of area

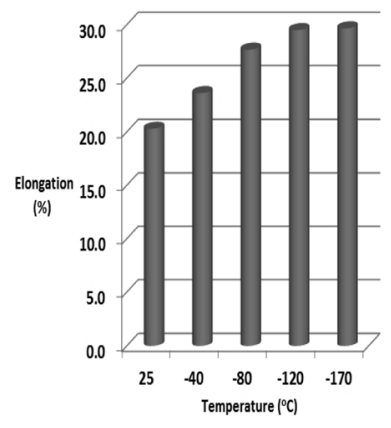

(b) Elongation
Fig. 6. Comparison of reduction of area and elongation for specimens.

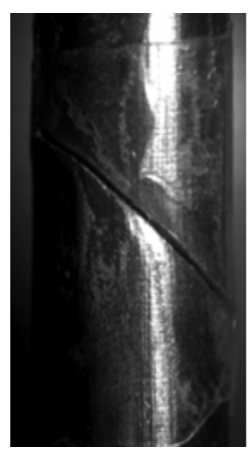

(a) R.T.

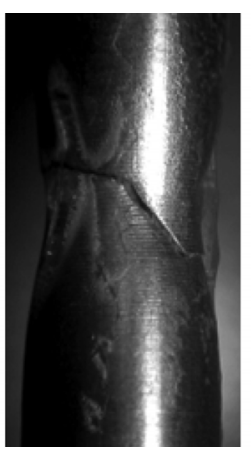

(b) $-80^{\circ} \mathrm{C}$

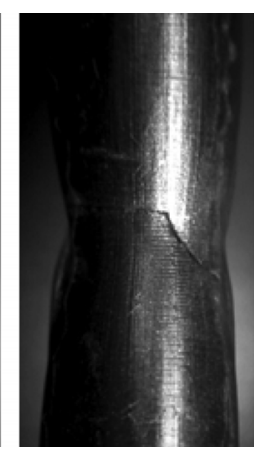

(c) $-120^{\circ} \mathrm{C}$
Fig. 7. Fractures of Al 5083 alloy at different temperatures.
면서 평형부 전체가 골고루 가공경화를 받아 국부 네킹을 방지하기 때문에 강도가 $-40^{\circ} \mathrm{C}$ 보다 높게 나타난다.

Fig. 6은 연신율 및 단면감소율에 대한 결과를 나타낸 것 으로 온도가 낮아짐에 따라 증가하는 경향을 보인다. 단면 감소율의 경우, 상온에서 결과 값이 매우 작은 것을 알 수 있다. 이것은 Fig. 7 에서 보는 것과 같이 상온에서 네킹 현 상이 발생하지 않아 얻어진 결과이다.

\section{2. 피로시험 결과}

피로시험은 응력비 $(\mathrm{R})=0.1$, 부하 속도는 $25 \mathrm{~Hz}$ 로 하 였다. Fig. 8 은 상온과 $-170^{\circ} \mathrm{C}$ 에서의 피로시험 결과를 응 력 진폭과 파단 수명의 관계로 나타낸 것이다. 일반적으 로 실제 적용되는 $\mathrm{LNG}$ 선과 같은 저온 조건에서의 피로강 도는 증가하는 것으로 알려져 있으며 본 연구를 통하여 $\mathrm{Al} 5083$ 합금에 대한 피로강도는 저온으로 갈수록 향상되 는 것을 확인 할 수 있다.

\section{3. 피로시험 결과의 통계적 처리}

Fig. 9와 10은 온도에 따른 $\mathrm{Al} 5083$ 합금에 대한 확률분 포 P-S-N 선도를5) 보여주고 있다. 실선은 파괴 확률 $50 \%$ 의 선이고, 점선은 $10 \%$ 의 선, 1 점 쇄선은 파괴확률 $90 \%$ 의 P-S-N 선도를 나타낸다.

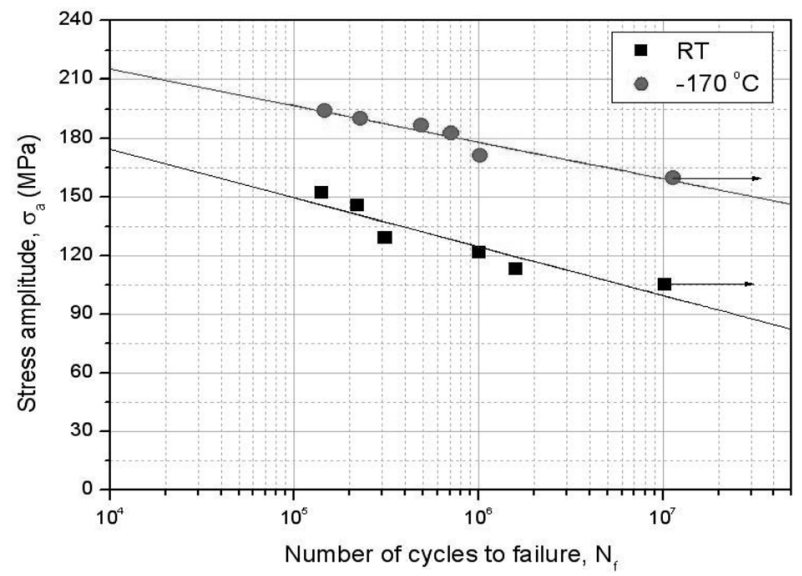

Fig. 8. S-N curves of fatigue test for Al 5083-G1.

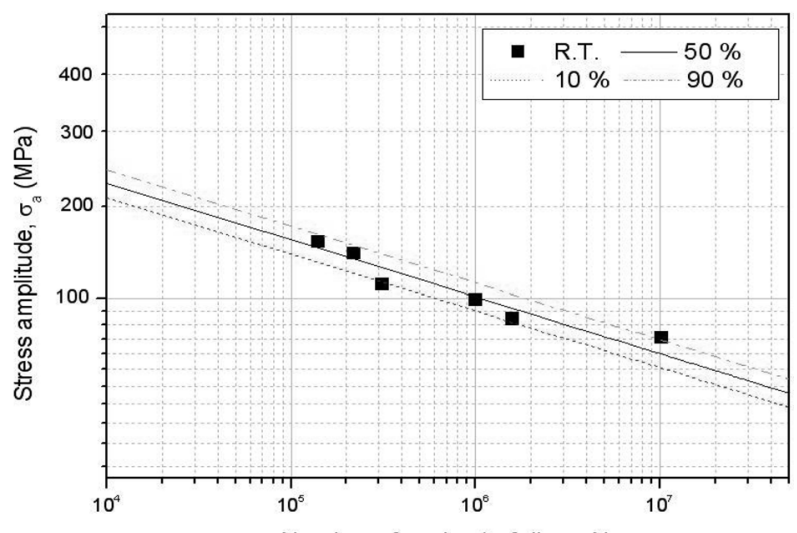

Number of cycles to failure, $\mathrm{N}_{\mathrm{f}}$

Fig. 9. P-S-N curves at R.T. condition. 
$\hat{\sigma}(\log N)=\left[\frac{1}{6} \sum_{i=1}^{n} \log N_{i}-\left(\widehat{\alpha_{2}}+\widehat{\beta}_{2} \log S_{i}\right)^{2}\right]^{\frac{1}{2}}$

위 식을 이용하여 상온 데이터를 이용하여 구해진 계수 $\hat{\alpha}_{2}=373.2492, \hat{\beta}_{2}=-0.09482$ 로 계산된다. Table 2와 3에서 파 괴확률 선도를 나타내고 있다. 본 연구 결과로서 얻어진 온 도 변화에 따른 파괴확률 $10 \% \mathrm{P}-\mathrm{S}-\mathrm{N}$ 선도는 $\mathrm{LNG}$ 선의 설 계에 있어서 $\mathrm{Al} 5083$ 합금의 피로강도 설계 기준으로 유용 하게 사용할 수 있을 것으로 사료된다 ${ }^{6,7)}$.

본 실험 결과로부터 피로강도를 평가하는 경우 실선에서 의 구속조건에 의한 것과 비교할 때 더욱 안전함을 알 수 있다.

Table 2. P-S-N curves for fracture probability of fatigue test at R.T.

\begin{tabular}{c|c}
\hline $\begin{array}{c}\text { Fracture } \\
\text { probability }\end{array}$ & P-S-N curves \\
\hline \hline $50 \%$ & $\log \mathrm{N}=373.2492+(-0.09482) \log \mathrm{S}$ \\
\hline $10 \%$ & $\log \mathrm{N}=353.6681+(-0.09482) \log \mathrm{S}$ \\
\hline $90 \%$ & $\log \mathrm{N}=393.9144+(-0.09482) \log \mathrm{S}$ \\
\hline
\end{tabular}

Table 3. P-S-N curves of fracture probability for fatigue test at $-170^{\circ} \mathrm{C}$

\begin{tabular}{c|c}
\hline $\begin{array}{c}\text { Fracture } \\
\text { probability }\end{array}$ & P-S-N curves \\
\hline \hline $50 \%$ & $\log \mathrm{N}=287.5286+(-0.04952) \log \mathrm{S}$ \\
\hline $10 \%$ & $\log \mathrm{N}=281.1194+(-0.04952) \log \mathrm{S}$ \\
\hline $90 \%$ & $\log \mathrm{N}=294.0840+(-0.04952) \log \mathrm{S}$ \\
\hline
\end{tabular}

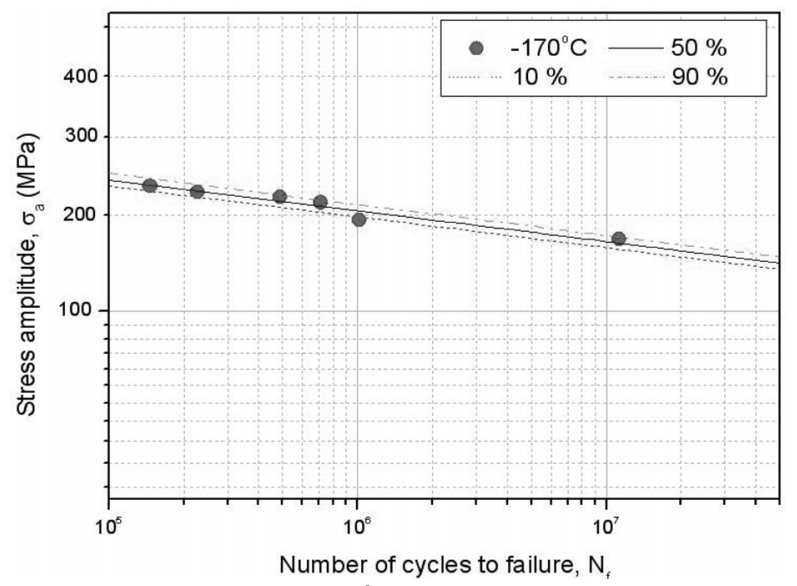

Fig. 10. $\mathrm{P}-\mathrm{S}-\mathrm{N}$ curves at $-170^{\circ} \mathrm{C}$ condition.

\section{4. 개재물의 정성, 정량 분석}

열 페놀법으로부터 추출해낸 개재물의 침상 또는 막대, 다각형의 성분을 $\mathrm{EDX}$ 분석한 결과를 에 Table 4와 Fig. 11 에 나타내었다. $\mathrm{Al} 5083$ 합금은 주로 $\mathrm{AlMn}, \mathrm{MgSi}, \mathrm{MnSiAl}$ type의 금속간화합물을 포함하고 있고 XRD 분석을 통해 확 인하였다. Fig. 12는 XRD 분석한 결과 이다.

$\mathrm{Mg}_{2} \mathrm{Si}$ 와 $\mathrm{Mn}_{12} \mathrm{Si}_{7} \mathrm{Al}_{5}$ 의 개재물은 기계적 특성에 부정적 영향을 미치기 때문에 연신율 및 파괴인성 등 기계적 성질 을 감소시킨다. $\mathrm{Al}_{6} \mathrm{Mn}$ 의 경우 전기화학적으로 알루미늄 기지내에서 안정하고 내식성이 풍부하며, 적당한 강도와 성

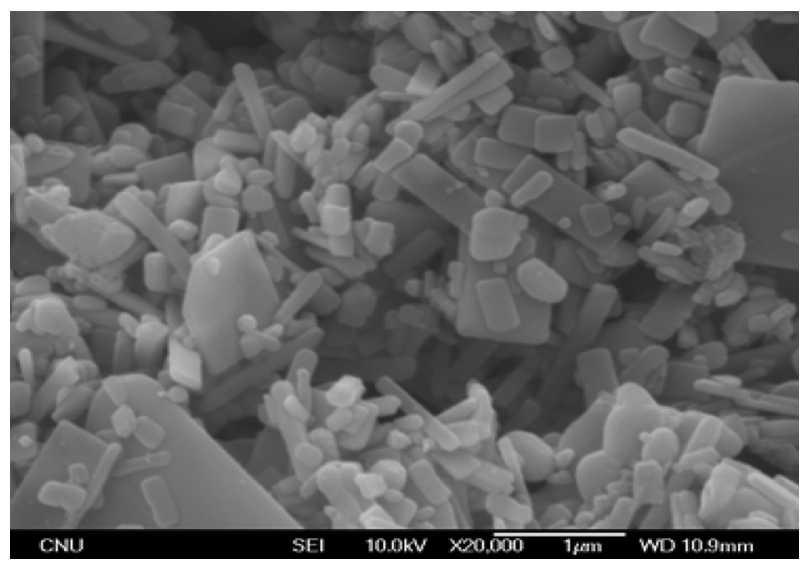

(a) $\mathrm{Al}_{6} \mathrm{Mn}$

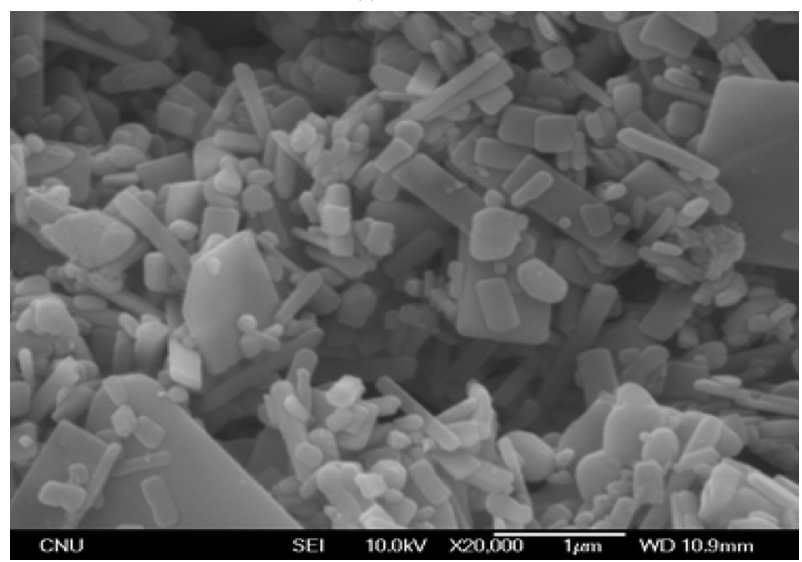

(a) $\mathrm{Mg}_{2} \mathrm{si}$

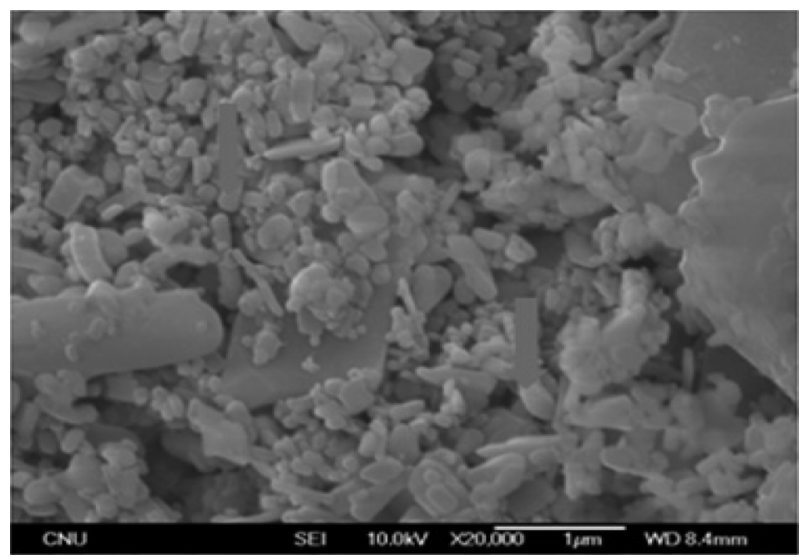

(b) $\mathrm{Mn}_{12} \mathrm{Si}_{7} \mathrm{Al}_{5}$

Fig. 11. SEM and EDX of $\mathrm{Al}_{6} \mathrm{Mn}, \mathrm{Mg}_{2} \mathrm{Si}$ and $\mathrm{Mn}_{12} \mathrm{Si}_{7} \mathrm{Al}_{5}$ for $\mathrm{Al} 5083$ alloy.

Table 4. Chemical composition of intermetallic compound

\begin{tabular}{c|c|c|c}
\hline \multicolumn{4}{c}{ Chemical composition (\%wt) } \\
\hline \hline \multirow{4}{*}{ Phase } & 1 & 2 & 3 \\
\cline { 2 - 4 } & $\mathrm{Al}: 70.1$ & $\mathrm{Mn}: 16.9$ & $\mathrm{Mg}: 60.3$ \\
& $\mathrm{Mn}: 21.3$ & $\mathrm{Si}: 1.4$ & $\mathrm{Si}: 39.7$ \\
\cline { 2 - 4 } & & $\mathrm{Al}: 67.4$ & \\
\cline { 2 - 4 } & $\mathrm{Al}_{6} \mathrm{Mn}$ & $\mathrm{Mn}_{12} \mathrm{Si}_{7} \mathrm{Al}_{5}$ & $\mathrm{Mg}_{2} \mathrm{Si}$ \\
\hline
\end{tabular}

형성을 지니게 하여 강도를 향상시키고 쾌삭상을 좋게 하 는 등 기계적 성질을 향상시키는데 도움을 준다, ${ }^{89}$. 또한, 결 


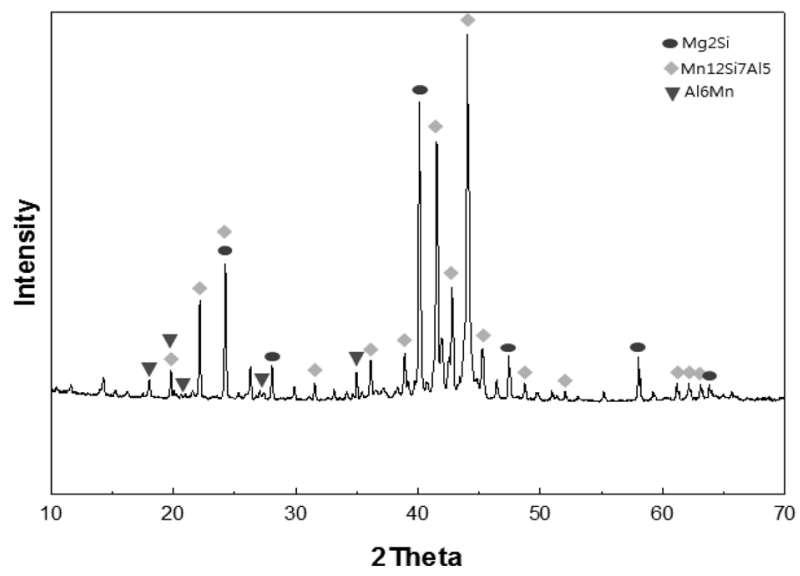

Fig. 12. The X-ray diffraction of the particles extracted from Al 5083 alloys.

정립 크기가 작고 조대한 개재물의 양이 상대적으로 적으 며, 미세한 $\mathrm{Mn}$ 분산상이 고르게 퍼져있어 전위의 이동을 방해하여 연성과 강도를 향상시킨 것으로 보인다 ${ }^{10)}$.

\section{4. 결 론}

본 연구로부터 극저온 하에서 $\mathrm{LNG}$ 선 내벽용으로 개발 중인 $\mathrm{Al} 5083$ 합금의 인장 및 피로 시험을 통해 특성평가를 실시하였으며, 소재에 대한 개재물 추출을 통하여 다음과 같은 결론을 얻었다.

1) 항복강도와 인장강도는 상온 $\sim-80^{\circ} \mathrm{C}$ 범위에서 온도 가 낮아짐에 따라 다소 감소하는 경향을 보인 후 $-120^{\circ} \mathrm{C}$ 이 후 증가하는 것을 알 수 있다. 강도가 상온과 저온에서 높고 중간 온도에서 낮은 이유는 하중-변위 선도에서 나타나는 톱니형상과 관계가 있을 것으로 사료된다.

2) 연신율 및 단면감소율의 결과는 온도가 낮아짐에 따라 증가하는 경향을 보인다. 단면감소율의 경우, 상온에서 결과 값이 매우 작다. 이것은 상온에서 네킹 현상이 발생하지 않 아 얻어진 결과 때문이라고 판단된다.

3) 피로강도는 저온으로 갈수록 향상된다. 또한, 온도 변 화에 따른 파괴확률 P-S-N 선도는 Al 5083 합금의 피로강 도 설계 기준으로 유용하게 사용될 수 있다. 본 실험 결과로 부터 피로강도를 평가하는 경우 실선에서의 구속조건에 의 한 것과 비교할 때 더욱 안전함을 알 수 있다.

4) $\mathrm{Al} 5083$ 합금은 결정립 크기가 작고 조대한 개재물의 양이 상대적으로 적으며, 미세한 $\mathrm{Mn}$ 분산상이 고르게 퍼져 있어 전위의 이동을 방해하여 연성과 강도를 향상시킨 것으 로 판단된다.
감사의 글: 본 연구는 (주) 동양강철 연구비 지원에 의해 수행되었습니다.

\section{참고문헌}

1) S. J. Kim, S. K. Jang and M. S. Han, "Evaluation of Mechanical Characteristic of Al Alloy for Ship's Welded with Various Welding Techniques," Journal of the Korean Society of Marine Environment \& Safety, Vol. 13, No. 3, pp. 223-228, 2007.

2) J. H. Hwang and D. H. Park, "Fatigue Characteristic of Welded Al 5083 Alloy-0" Annual Meeting of KWJS, No. 2, pp. 205-209, 1992.

3) ASTM E8, "Standard Test Methods for Tension Testing of Metallic Materials", ASTM International, pp. 1-24, 2004.

4) ASTM E466, "Standard Practice for Con- ducting Force Controlled Constant Amplitude Axial Fatigue Tests of Metallic Materials", pp. 1-5, 2007.

5) JSME S 002, "Standard Method of Statistical Fatigue Testing", Journal of the Japan Society of Mechanical Engineers, pp. 10-42, 1994.

6) K. S. kim, S. H. Boo, C. Y. Park, Y. G. Cho and J. S. Lee, “An Experimental Study on the Tensile and Fatigue Strengths of SUS304L Lap Joint Weld at the Cryogenic Temperature", Int. J. of KCORE, Vol. 22, No. 3, pp. 96-102, 1992.

7) H. J. Shim, I. H. Jeon and J. K. Kim, "Effective of Stress Ratio on the Fatigue Strength of Welding Part in the LNG Containment System", Fall Annual Meeting of KSME, pp. 201-206, 2009.

8) J. M. Lee, J. H. Yoon, K. H. Kim and H. G. Kim, "Control of Inclusion in Aluminum Alloys", Journal of the Korean Foundrymen's Society, Vol. 23, No. 1, pp. 15-22, 2003.

9) J. M. Kim, J. S. Park, H. Y. Kim, J. I. Cho and C. Y. Jung, "Effects of Mn, Cr and Sr Additions on the Microstructure and Tensile Properties of Al-7Si-0.4Mg-1Fe Casting Alloy", Journal of the Korean Foundrymen's Society, Vol. 29, No. 1, pp. 27-32, 2009.

10) J. An, K. H. Moon and K. H. Lee, "A Study on the Measurement of the Concentration and the Size Distribution of Inclusions in the Molten Aluminum", Journal of the Korean Foundrymen's Society, Vol. 14, No. 1, pp. 62-74, 1994. 